\title{
G. Sanneris
}

\section{SUPPORT OF SME'S IN ITALY: CASE OF CONFIDI, EXPERIENCE AND PERSPECTIVES OF EVOLUTION}

\author{
Д. Саннерис
}

\section{ПОДДЕРЖКА МАЛОГО И СРЕДНЕГО ПРЕДПРИНИМАТЕЛЬСТВА В ИТАЛИИ: ДЕЯТЕЛЬНОСТЬ ОБЩЕСТВ CONFIDI, ОПЫТ И ПЕРСПЕКТИВЫ РАЗВИТИЯ}

The paper traces the chronicle of the development of Italian Confidi and of the critical pivotal and actual issues of Confidi, so to offer an appropriate frame to introduce the draft of reform of Confidi, actually under review of the Italian legislative system, and the considerations and proposals of the author concerning the theme. Object of this paper is the analysis of the historical and juridical development of Italian mutual guarantee societies. The article analyses origins and initial development of the system of mutual support for small and medium sized enterprises (SMEs), and Confidi Framework Law, issued in 2003. The paper regards AECM experience in supporting the development of SMEs. AECM is the European Association of Guarantee Institutions. Aim of their members is, each in their country, to support access to credit for small and mediumsized enterprises (SMEs). Of particular interest among historical members of AECM are to be considered the Italian members of AECM, both for volumes of guarantees issued in relation with national GDP both for number of members. Guarantees societies in Italy are historically private, mutual, and are named Confidi. The author describes Confidi structure, hierarchy and role of the Bank of Italy in the system of support to small and medium sized business in the country, being supported by recent economic and financial data of Confidi's evolution and in consideration of the ultimate approval, on July 2015, by Italian Senate, of the draft of law about a substantial reform of the argument. The author offers a critical analysis of the actual draft and concludes by proposing some considerations about the reform. The ways of further development of small entrepreneurship in Russia are proposed.

ENTREPRENEURSHIP; SMALL AND MEDIUM SIZED BUSINESS; ITALIAN MUTUAL GUARANTEE SOCIETIES; CONFIDI; DEVELOPMENT OF SYSTEM OF SMALL BUSINESS SUPPORT.

Выполнен обзор истории развития и анализ опыта общества взаимного кредита Confidi с целью предложить направления реформирования итальянского законодательства в области регулирования процессов поддержки малого бизнеса. Объектом исследования являются общества взаимного кредита, созданные ассоциациями работодателей и ремесленников. Рассмотрены происхождение и развитие системы взаимной поддержки малого и среднего предпринимательства, действующий закон о таких сообществах, принятый в 2003 г. Рассматривается взаимосвязь обществ с Европейской ассоциацией гарантийных институтов (АЕСМ). Целью создания данных сообществ является взаимная поддержка членов, малых и средних предприятий, путем повышения доступности кредитов. Главный акцент сделан на опыте итальянских сообществ Confidi, обеспечивающих значительный объем кредитов. Итальянские общества взаимных гарантий являются частными организациями и есть результат инициативы ассоциаций предпринимателей и ремесленников. Анализируются иерархия, структура Confidi и роль Банка Италии в системе поддержки малого и среднего предпринимательства в стране и контроле деятельности Confidi, а также экономические показатели Confidi; приведены статистические данные. Автор анализирует на основе статистических данных различие в результатах деятельности Confidi в Северной и Южной Италии, дает объяснение этому феномену, в частности приводит структуру рынка Confidi и выделяет ключевые факторы, определяющие эти различия. Описаны специфические особенности политики в области поддержки малого и среднего бизнеса в условиях кризиса, приведены соответствующие стати- 
стические данные. Выявлены проблемы и барьеры на пути реализации задач Confidi, выполнен критический анализ предложений по совершенствованию итальянского законодательства, в частности проекта реформ 2015 г. - проекта Закона № 1259. Предложен ряд мер по совершенствованию системы поддержки малого бизнеса.

ПРЕДПРИНИМАТЕЛЬСТВО; ЕВРОПЕЙСКИЙ БИЗНЕС; ПОДДЕРЖКА МАЛЫХ И СРЕДНИХ ПРЕДПРИЯТИЙ В ИТАЛИИ; ОПЫТ ООБЩЕСТВ CONFIDI; ПЕРСПЕКТИВЫ РАЗВИТИЯ.

1. Introduction. Confidi are mutual guarantee societies primarily promoted by employers' associations (manufacturers, traders, craftsmen), which directly operates in favour of member companies by issuing guarantees for bank loans granted to SMEs associated. The historical aim of the Confidi is to facilitate credit access for smaller enterprises.

In Italy, a Confidi represents a pivotal financial and economic actor in the supply chain in the process of granting credits to SMEs. The history of the Confidi, as well as their development, is indissolubly connected to Italian industrial development, since the Italian industrial system is characterized by a dominant presence of SMEs, mainly of micro and small dimensions.

It is therefore essential, in order to support Italian industrial development, to ensure the sustainable and organic development of the Confidi, particularly by means of legislative instruments, leading them towards a progressive and inevitable structural and operative reorganization.

The analysis of the evolution process of the Confidi, both at a historical and a legislative level enables a more factual comprehension of the actual difficulties they are facing and introduces the proposals for solving these difficulties.

\section{History of the Confidi}

a) Origins and initial development

An instrument of financial guarantee which supported the creation of the cooperative of mutual guarantee as a juridical figure was introduced in the Italian system in 1956 with the issue of organic legislation about craftsmen. Towards the constitution of this juridical figure, which offered guarantees for loans requested from associated craftsmen, public funds were provided in order to support and promote the diffusion of private activity. The first cooperative of mutual guarantee for craftsmen was constituted in 1957, while the diffusion of industrial consortia and cooperatives in the industrial field to guarantee loans requested by the associated in order to allow access to credit for Italian SMEs started only in the 1960s, and only partially, because of the initial lack of an authorized established juridical form, afterwards identified as a consortium or cooperative. The support of the Confidi becomes essential in the 1970s, with the Italian economic crisis and the connected difficulties of Italian SMEs to be financed by credit institutions. The first national federation of Confidi, named Federconfidi, was founded in 1971 in the manufacturing field, and the first regulation of their activity which recognized their contribution to SME development was issued in 1977 and granted them favourable fiscal treatment, the possibility to obtain public aid from regions and from other forms of local government, the recognition of the mutual non-profit spirit of the Confidi. It was in this period that the central fond of guarantee by Mediocredito Centrale ${ }^{1}$ was introduced.

The leading role of the Confidi as collective credit guarantors within the Italian entrepreneurial system was recognized in $1991^{2}$. The Italian law defined them as «granting financial activity to SMEs and providing essential information for a more accurate evaluation and rating of SMEs in credit intermediation». Their effective role in reducing the asymmetric information afflicting credit intermediaries evaluating SMEs interested in access to credits was furthermore identified. Italian law introduced the minimum requirements for the Confidi with regard to enterprise shareholders and capital requirements. A fund of

\footnotetext{
1 Mediocredito Centrale was created in 1952 as a public law institution to distribute public financial aid, facilitations and support to the process of internationalisation of SMEs; in 1994 becomes a public company of private law held by state entities also aimed to Project \& Export Finance, industrial finance and loans, leasing and factoring; today it is a Bank aimed at supporting the development of Southern Italy and of Italian SMEs, offering financing for SMEs, loans for private, management of European and national distribution of funds on behalf of the public administration).

${ }^{2}$ Law No. 317/1991.
} 
guarantee was created to absorb losses due to non-performing credits guaranteed to SME shareholders. The fund of guarantee is guaranteed and covered up to $30 \%$ by the State. The operative skeleton of the Confidi took shape with the establishment of the National Federations of Confidi and of the National Coordination of Confidi (mainly with representative functions). National, regional and interregional forms of agreement and coordination of the Confidi are progressively instituted. The general reform of the bank codification, in the 1990s, imposed registration of the Confidi in a special list of financial institutions, in accordance with criteria established by the Consolidated Law on Banking, so-called TUB. Confidi are listed in a special section of the new TUB and are consequently obliged to fulfil financial statements in accordance with the provisions of the Bank of Italy; new measures are approved, like the anti-usury fund and the possibility for Confidi to counterguarantee or co-guarantee bank bonds.

b) Confidi Framework Law, 2003

It was in 2003 that the Italian legal system witnesses a general reform on the discipline regulating the Confidi, by means of the so-called Confidi Framework Law ${ }^{4}$.

3 The Bank of Italy is the central bank of the Republic of Italy. It is a public-law institution regulated by national and European legislation. It is an integral part of the Eurosystem, which is made up of the national central banks of the euro area and the European Central Bank. The Eurosystem and the central banks of the member states of the European Union that have not adopted the euro make up the European System of Central Banks.

The Bank pursues aims in the general interest in the sector of money and finance: price stability, which is the main objective of the Eurosystem under the Treaty on the Functioning of the European Union; the stability and efficiency of the financial system, thus implementing the principle of the protection of savings embodied in the Constitution (Article 47 states «The Republic encourages and protects saving in all its forms, it regulates, coordinates and controls the provision of credit»); and the other duties entrusted to it by Italian law. As regards supervision, the Bank of Italy is the competent national authority for the Single Supervisory Mechanism (SSM) for banks.

4 Article 13 of Legislative Decree No. 269 dated 30 September 2003, transformed into Law No. 326 of 24 November 2003.
The main constituents of the Confidi Framework law are listed in the following Scheme:

\section{Main Costituents of the Confidi Framework Law}

\begin{tabular}{|c|c|}
\hline Legal status & $\begin{array}{l}\text { Establishment of legal status: consortia } \\
\text { with external activity; } \\
\text { cooperative society; limited liability or } \\
\text { share capital consortium }\end{array}$ \\
\hline \multirow[t]{2}{*}{$\begin{array}{l}\text { Company } \\
\text { object }\end{array}$} & $\begin{array}{l}\text { exclusively focused on activities concerning } \\
\text { joint credit; } \\
\text { guarantee-granting and related or } \\
\text { instrumental services }\end{array}$ \\
\hline & Mutual non-profit activity \\
\hline \multirow[t]{2}{*}{$\begin{array}{l}\text { Registered } \\
\text { capitai }\end{array}$} & $\begin{array}{l}\text { Consortium fund or share capital not less } \\
\text { than } € 100.000 \text {, with the exception of } \\
\text { certain consortia that must comply with } \\
\text { the threshold; } \\
\text { amount of } € 120.000 \text {, as provided for by } \\
\text { the civil code }\end{array}$ \\
\hline & $\begin{array}{l}\text { Threshold share for each company set at } \\
€ 250 \text {; } \\
\text { shares may not exceed } 20 \text { per cent of } \\
\text { share capital }\end{array}$ \\
\hline \multirow[t]{2}{*}{ Equity } & $\begin{array}{l}\text { Equity including risk funds less than } \\
€ 250.000\end{array}$ \\
\hline & $\begin{array}{l}\text { Contributions by members/shareholde } \\
\text { not less than one fifth of the equity }\end{array}$ \\
\hline \multirow[t]{3}{*}{$\begin{array}{l}\text { Associate } \\
\text { companies }\end{array}$} & $\begin{array}{l}\text { SMEs, as defined by the EU regulations } \\
\text { (number of employees below } 250 \text {; } \\
\text { turnover less than } € 50 \text { million; total } \\
\text { assets less than } € 43 \text { million) }\end{array}$ \\
\hline & $\begin{array}{l}\text { Companies of larger dimensions, within } \\
\text { the boundaries set by the European } \\
\text { Union, with regard to EIB interventions } \\
\text { in favour of SMEs (fewer than } 500 \\
\text { employees, net fixed assets up to } € 75 \\
\text { million); companies exceeding the above } \\
\text { parameters may not hold more than one } \\
\text { third of shares), as more as they } \\
\text { represent not more than one sixth of the } \\
\text { associated companies }\end{array}$ \\
\hline & $\begin{array}{l}\text { Companies of greater dimensions compared } \\
\text { to the previously mentioned ones, only } \\
\text { provided their share of capital was } \\
\text { underwritten prior to the coming into } \\
\text { effect of the Framework Law on Confidi }\end{array}$ \\
\hline $\begin{array}{l}\text { Subject } \\
\text { requirements }\end{array}$ & $\begin{array}{l}\text { Subject holding shares and subjects with } \\
\text { administrative, management and supervision } \\
\text { duties must comply with fit and proper } \\
\text { persons' tests }\end{array}$ \\
\hline
\end{tabular}


Confidi Framework Law introduced 3 organizational models of the Confidi:

a) A traditional model of the Confidi entered in a special list referred to in article 106 TUB (henceforth Confidi 106);

b) The Confidi of financial intermediaries entered in the special list referred to in art. 107 of TUB (henceforth Confidi 107);

c) The Confidi Guarantee banks

Here are the main features of each organizational model:

a) Confidi 106 - they are obliged to be registered in a special list. Core activity limited to collective loan guarantees and connected, as well as instrumental, services (i. e. advisory services, or outsourcing of information services). Handling of public funds is limited to a temporarily period of three years.

b) Confidi 107 - Financial intermediaries supervised by Bank of Italy. The Confidi whose guaranteed activities and assets exceed a certain limit set by the Ministry of Finance must be established in this form ${ }^{5}$.

They are entitled to:

- as predominant activity, issue Basel-compliant guarantees and counter-guarantees, as well as guarantee-related and instrumental activities, respecting fixed parameters of profitability and dimensions. In other words, they can provide, mainly to SME shareholders, collective loan guarantees; in addition, they can offer guarantees to the State as well as stipulate contracts with banks' assignees of public guarantee funds;

- as residual activities_(within the limit of $20 \%$ of the total assets), they are allowed other activities carried out by financial intermediaries 107 TUB (exchange intermediation, underwriting shares, loans, payment services).

Confidi 107 are subjected to the application of regulatory framework equivalent to that of banks. This allows to obtain the best possible prudential treatment provided by credit risk mitigation (CRM) as per Basel II, as a more favourable risk weighting is applied to bank loans granted by the Confidi, and as the guarantees offered by such intermediaries are recognized as reducing the lending bank's credit risk.

${ }^{5}$ In particular, the passage to Confidi 106 (minor Confidi) to Confidi 107 is mandatory when, according to financial statements, the volume of financial activity is more than 75 million euros. c) Confidi guarantee banks - established in the form of cooperative Confidi 107 compared to Confidi 106 societies and recorded in a special list, their predominant activity must be mainly joint loan guarantee-granting activities to the advantage of their shareholders. They may additionally offer banking activities, as well as related and instrumental services. Since they are considered compatible, TUB regulations for cooperative banks also apply to Confidi guarantee banks.

\begin{tabular}{|c|c|}
\hline Competitive advantages & Disadvantages \\
\hline $\begin{array}{l}\text { guarantor admitted in the credit } \\
\text { risk mitigation }\left(\mathrm{CRM}^{6}\right) \text {; } \\
\text { able to offer: loans, advice on } \\
\text { the treasury management and } \\
\text { corporate banking services; } \\
\text { able to diversify type of guarantees } \\
\text { issued } 8 \text { according to the approach } \\
\text { adopted by the bank for capitl } \\
\text { provisions related to credit risk; } \\
\text { management of public incentive } \\
\text { funds without restrictive conditions; } \\
\text { access to tender calls for } \\
\text { allocation of public resources } \\
\text { (i. e. fund for financing enterprises); } \\
\text { able to access international channels } \\
\text { of counter-securities and reinsurance }\end{array}$ & $\begin{array}{l}\text { respect of supervisory } \\
\text { standards regarding } \\
\text { organizational } \\
\text { arrangements, quality } \\
\text { of management, ...; } \\
\text { high compliance costs; } \\
\text { transparency of cost } \\
\text { structure and risks }\end{array}$ \\
\hline
\end{tabular}

c) 2003-2010

The business model of Italian mutual guarantee societies, defined as 'Confidi', changed radically at the end of the first decade of the twentieth century.

Two factors contributed to this change:

1. The regulations issued by the Bank of Italy requiring mutual guarantee societies with assets exceeding Euro 75 million to apply for inclusion

${ }^{6}$ In Pat II, Chapter 2 of Circular letter 263/2006, issued by the Bank of Italy, CRM (credit Risk Mitigation) techniques are defined as the set of instruments that can be employed by banks as credit protection. The procedures for allocating different types of credit protection depend on which approach is adopted by banks in calculating credit risk capital requirements (standardized, foundation IRB or advanced IRB). Anyhow the pressing requirements of Basel II have made it impossible to acknowledge guarantees issued by Confidi 106 with regard to credit risk mitigation. 
in the Register of Regulated Intermediaries, and hence to be subjected to the Bank of Italy supervision;

2. The government measure adopted to recapitalize the Central Guarantee Fund, the main activity of which was the backing up of the guarantees provided by the fund with an ultimate guarantee by the State.

Prior to the issue of the Bank of Italy regulations, mutual guarantee societies were not subjected to capital requirements. Their management was focused exclusively on the management of counterparty risk.

For the first time, Bank of Italy introduced an obligation for mutual guarantee societies to comply with capital requirements. This obligation changed their approach to market: risk management continues to play an important role in the management of the Confidi, but the strategic element for development is now 'capital'. The significant capital size enables mutual guarantee societies to expand their operations and reach the critical mass which is mandatory in order to cover the additional costs associated with supervision, and accordingly to manage their business efficiently. Thus 'capital' is referred to as a strategic element for development and this new element creates a remarkable contrast with the previously existing legislation resulting from the historical times, as mutual guarantee societies were the result of a mutualistic, no profit spirit, which concretely limited in a significant way the ability of a mutual guarantee society to attract venture capital.

Support for the repositioning of the Confidi was offered by the Italian Government, which radically changed the nature of the Central Guarantee Fund ${ }^{7}$.

7 The Central Guarantee Fund is a public fund created after the turn of the millennium in order to facilitate access to credit for SMEs. Until 2008, the fund's activity was relatively modest: it was used on a highly sporadic basis by banks and mutual guarantee societies for more problematic transactions. The fund theoretically provided risk coverage (it covered between 60 per cent and 90 per cent of exposure) though its administrative management was so complex that it significantly reduced any interest in its use. Furthermore, the guarantees issued by the fund did not provide any advantage in terms of capital reduction.
The Fund was recapitalized, equity was increased but the most relevant element was the provision of coverage for the guarantees issued by the Fund by an ultimate guarantee from the State. This measure enables the Confidi that are in turn guaranteed by the Fund not only to cover their risk but also to reduce capital absorption. The intervention of the Central Guarantee Fund made it possible for major mutual guarantee societies to increase their support for SMEs without any increase in risk and without causing any particular tensions in terms of the parameters measuring their intermediary's solvency.

The major Confidi not only relied on the Central Fund but also used all other instruments which public operators (regions, provinces, Chambers of Commerce, etc.) activated in order to facilitate access to credit for SMEs.

Of particular relevance is the credit limit made available by $E I F^{8}$ (European Commission's instrument of economic policy) for intervention in favour of SMEs.

Over this decade the major mutual guarantee societies have gradually transformed themselves from guarantor bodies into organizations acting as intermediaries which distribute guarantee instruments activated by public authorities.

Furthermore, the economic crisis and the tensions within the banking system on the liquidity front have strongly accelerated the trend of the aggregation process already in act within the mutual guarantee societies.

${ }^{8}$ The European Investment Fund (EIF), www.elf.org, as Europe's leading developer of risk financing for entrepreneurship and innovation, has been established to provide access to finance for SMEs. EIF delivers a wide range of innovative financing solutions for micro, small and medium-sized enterprises throughout Europe. These solutions, including equity, guarantees, credit enhancement and microfinance, are delivered through financial intermediaries. EIF's objective is to support EU policy objectives especially in the fields of innovation, technology, growth, employment, entrepreneurship and regional development, while at the same time acting as a market-oriented organization, which achieves an appropriate return on its capital through commercial pricing and a good balance of fee and risk-based income. EIF has a unique tripartite shareholding structure combining private and public investors: the European Investment Bank (EIB), $62 \%$, the European Union through the European Commission (EC), $30 \%$, and 25 public and private financial institutions, $8 \%$. 
The aggregation process mainly had its effects in Northern Italy, whereas in Southern Italy there remained a variety of smaller and less competitive Confidi. The aggregation process also lead to a National Unitarian Representative Organization of Confidi, «Asso Confidi»". The new association's aim was the representation, at EU level, of the Italian Confidi in $\mathrm{AECM}^{10}$ and, at a national level, the creation of a unanimous voice able to debate with continuity and authority with the Bank of Italy and the Italian Ministry of Economy about the rules and laws regulating the activity of the national Confidi.

The hierarchy of representation of the Confidi and of their operative levels became the actual ones, which can be summarized in the following Scheme.

9 At the end of 2006 was created the organism «Asso Confidi» whose goal was to unify, as a representative unity, all the different federations of guarantee consortia acting in the fields of agriculture, craftsmen, commerce and manufacturing This new aggregation represented in 2006 more than 1 million of SMEs, producing a volume of guarantees able to distribute more than 22 milliard euros to all SMEs associated.

10 AECM, European Association of Guarantee Institutions, www.aecm.eu, is a European association the members of whom, each in their own European country, support healthy SMEs with a business project that would otherwise not be able to access loan finance due to a lack of collateral and own funds. By granting a guarantee, guarantee societies provide a substitute for the missing collateral and allow the credit institution to grant the loan by sharing in the default risk. Guarantee organisations have been set up in nearly all European Member States, as well as in Montenegro, Russia and Turkey. In addition, guarantee schemes also exist beyond Europe, e. g. in the US, Latin America, Asia and the Mediterranean region. AECM, as the European association of mutual guarantee societies, represents the interests of its national members towards the European institutions and multilateral bodies, such as the OECD, the World Bank and the Bank of International settlement AECM also acts as a platform for exchange between its members and provides technical information about the guarantee sector.

While in each European country there are one, maximum two associated members of AECM, Italy, because of its historical representative fragmentation, provides eight associated members, each of whom represent a particular category of interests. Each of them are a reflection of the variety of Confidi still existing in Italy.

\begin{tabular}{|c|l|}
\hline $\begin{array}{c}\text { Operative } \\
\text { level }\end{array}$ & $\begin{array}{l}\text { a) Confidi of the 1st level } \\
\text { The shareholders generally are SMEs to } \\
\text { whom Confidi issue direct guarantees. } \\
\text { b) Confidi of the 2nd level } \\
\text { Shareholders are Confidi of 1st level or both } \\
\text { SMEs and Confidi of the 1st level. They } \\
\text { mainly issue counter-guarantees and co- } \\
\text { guarantees to Confidi of the 1st level with } \\
\text { the aim of reducing risk supported by the } \\
\text { Confidi operating on provincial base }\end{array}$ \\
\hline $\begin{array}{c}\text { Represen } \\
\text { tative } \\
\text { level }\end{array}$ & $\begin{array}{l}\text { a) National Federations } \\
\text { Mainly with functions of coordination and } \\
\text { representation } \\
\text { b) National Coordination of Confidi } \\
\text { Unifies the 5 bigger National Federations } \\
\text { and performs tasks of coordination and } \\
\text { representation } \\
\text { c) AECM } \\
\text { European Association of Guarantee } \\
\text { Institutions } \\
\text { Represents the interests of its national } \\
\text { members towards the European institutions } \\
\text { and multilateral international entities }\end{array}$ \\
\hline
\end{tabular}

\section{d) Legislative Decree No. 141/2010: an} incomplete reform

Legislative Decree No. 141/2010 substitutes title V of TUB completely, in particular the part about financial intermediaries ${ }^{11}$.

A form of official prudential supervising was required for the Confidi. At the achievement of a certain volume of financial activity ${ }^{12}$ established by the Ministry of Economy and Finance,

11 The reasons submitting the reform were to be found in the restrictions induced by international regulations. In application of Basel II and in the perspective of the introduction of Basel III, which aimed at the enhancement of the capitalization of financial intermediaries and of the patrimonial operational requirement of coverage of exposures towards other financial enterprises, just adequate instruments of guarantees issued by supervised institutions, or of high rating, could be considered, in the purpose of risk mitigation and of capital consideration, able to reduce the capital requirements on the corresponding bank loans. The guarantees that Confidi can issue -mainly 'fidejussioni', a kind of personal guarantee - couldn't enable a reduction of the patrimonial requisites needed to lean to risk mitigation and patrimonial coverage.

${ }_{12}$ In particular 75 mil. euros for Confidi already registered as anterior Confidi 106; 150 mil. euros for Confidi of new enrolment (new application) in the Register of Regulated Intermediaries 
Confidi ought to enrol in the Register of Regulated national financial Intermediaries. The enrolled Confidi have an operational sphere of intervention wider than the non-enrolled Confidi.

Previous Confidi 107 essentially maintain the same supervision structure and are authorized to be registered in the Register of Regulated financial Intermediaries, directly organized and supervised by the Bank of Italy. Therefore they are qualified as financial intermediaries.

A system to supervise minor Confidi (mainly Confidi 106 in Confidi Framework Law of 2003) has also been introduced. A self-regulatory body, a legal entity of private law, is supervised regularly by the Bank of Italy, with organizational, statutory and financial autonomy. It is in charge of keeping the register of smaller and microcredit collective loan-guarantee entities, as well as of supervising the entities recorded in that register, with power of expulsion of non-compliant Confidi.

Both provisions are still waiting for a factual organic implementing regulation.

\section{Confidi and the crisis, the actual scenario:} some data

Some data to underline the effective support offered by Confidi to SMEs in the acute phase of the financial crisis: between 2007 and 2009 credit to enterprises guaranteed by Confidi has increased to an average annual $2.1 \%$, compared to an average annual decrease of $1.4 \%$ for enterprises not guaranteed by Confidi. At the end of 2009, the quota of loans issued to enterprises with less than 20 workers and guaranteed by Confidi represented about $13 \%$ of the total credit granted to enterprises with less than 20 workers from the entirety of the Italian bank system.

The data elaborated by AEGM clearly illustrate how in the years 2011 and 2012, the organization of Confidi, in the Tables referred to as Asso-Confidi, maintains its role of absolute predominance as a credit guarantor among AEGM associated in the EU scenario, supporting access of SMEs to credit.

Figure indicates the proportion of the outstanding guarantees in portfolio of each member towards AECM total comparing 2011 and 2012 (in \% of total).

In what concerns the cost reduction to access credit, at the end of 2007, enterprises guaranteed by Confidi obtained short-time loans to average rates of interests lower by 20 base points than others. Such a cost advantage extended during the crisis: at the end of 2009 the differential slightly increased arriving to 30 base points with particularly intense effects on the Southern Italy enterprises (1.4\% point), followed by the North-East and Centre enterprises (0.4\% and $0.5 \%$ point).

The structural discrepancies existing between Confidi dislocated in Southern Italy and other Confidi become evident, as in Southern Italy the crisis hit the manufacturing system harsher and enhanced credit grip. The general gap existing between Southern and Northern Italy can be summarized in the following points (Figure).

Southern Italy was just marginally involved in the drastic aggregation process of Confidi which occurred in the Northern and Central Italy in the 2000-2010 decade and which led to a connected reduction of their operative costs and to an enhancement of production efficiency;

- Dimensional parameters of the Southern Italian Confidi (average number of enterprises associated, capitalization) highlight the problem of their microscopic dimensions;

- The pathological low levels of net assets entail the issuing of guarantees of inadequate average amount and group them in the class of minor loans;

- In Southern Italy the indicators of average high solvency (net assets/ guarantees) reveal a particular cautious inclination in issuing guarantees as well as a less intensive exploitation of available resources.

Source is the Central Credit Register ${ }^{13}$ of the Bank of Italy.

Tab. 1 and 2 concerning the data of 2013 confirm the above-mentioned scenario, offering further information about the geographical coverage and sector allocation of collective guarantees with particular evidence on small enterprises, intended as not financial enterprise with less than 20 workers.

${ }^{13}$ The Central Credit Register ('Centrale dei Rischi') is an information system on the debts of the customers of the banks and financial companies supervised by the Bank of Italy.

The Bank of Italy collects information on customers' borrowings from the intermediaries and notifies them of the risk position of each customer visa-vis the banking system.

By means of the Central Credit Register the Bank of Italy provides intermediaries with a service intendedimprove the quality of the lending of the credit system and ultimately to enhance its stability. 


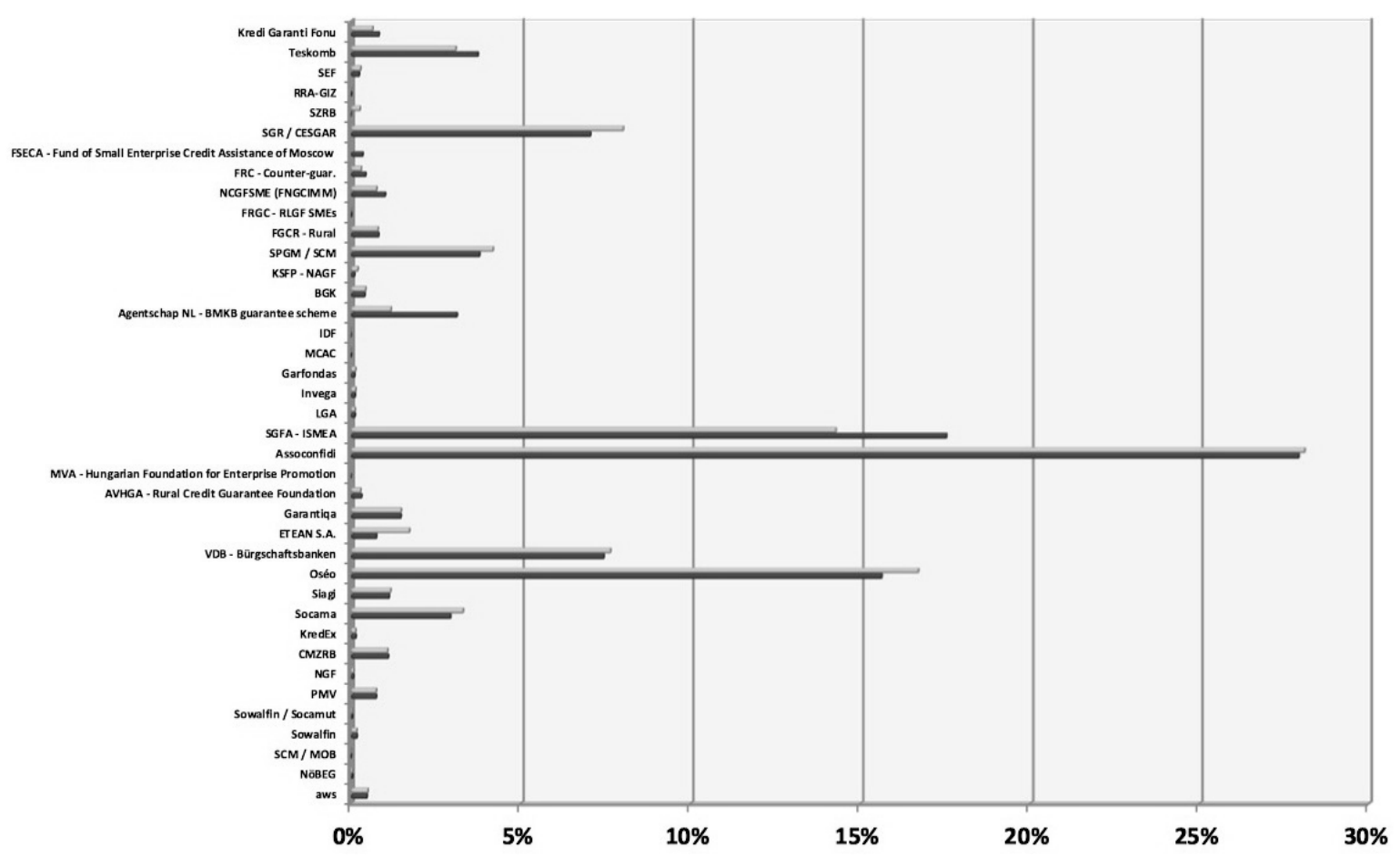

Proportion of the outstanding guarantees in portfolio of each member towards AECM total: comparison 2011 and 2012 figures (in \% of total AECM pordfolio)

( $\square)-2011$; ( $\mathbf{a})-2012$ (provisional figeres)

Tab. 1 summarizes the structural market of the Confidi by geographical allocation. At the end of 2013, of the 617 total number of Confidi registered in the register hold by Bank of Italy, 306 were based in Southern Italy, 133 were located in Central Italy and respectively 98 in North-West and 80 in North-East of the country. It is the evidence of the process of concentration which is clearly incomplete in Southern Italy, and more effective in other geographical areas of the country. The fragmentation in a multitude of small and microscopic organizations is corroborated by the data of the total amount of guarantees issued: the Southern Italian Confidi issue the more exiguous volume of guarantees, 3.9 bn euros in 2013, compared to 8.5 bn euros in North-West. The average value of issued guarantees in Southern Italy is just $17.7 \mathrm{~m}$ euros, almost a third of the average value at national level, equal to $43.6 \mathrm{~m}$ euros, whereas the maximum average amount issued in North-West is $97.1 \mathrm{~m}$ euros.

Also the average geographical operative area of intervention of Southern Italian Confidi, equal to 6.4 provinces, is reduced in comparison with the average Italian data, 11.3 provinces, and even more reduced in comparison with North-
West (18.7 provinces) and North-East (16 provinces).

Tab. 2 reports the percentage of non-performing guarantees over the guarantees issued in favour of small enterprises (defined as non-financial enterprises with less than 20 workers) according to geographical coverage and sectorial allocation in 2013.

Empirical evidence confirms theoretical expectations, whereas the rate of non-performing guarantees is reported to be lower in case of credits guaranteed by Confidi in comparison with credits not guaranteed by the Confidi. In fact, the activity of supervision and preliminary screening offered by the Confidi should emphasize the action of selection of the issuer bank, offering a sample of enterprises with a higher degree of solvency or at least reducing the overall asymmetry of information of the issuer bank due to a less penetrating level, on the side of the bank, of knowledge of the territory and the potential of each SME.

At a national level, the percentage of nonperforming credits out of the total of guaranteed credits is $16.2 \%$, whereas the percentage of nonperforming credits out of the total of credits not guaranteed by Confidi is $20.9 \%$. 
The organization of Confidi's market, by geographical areas, 31.12.2013 (*)

\begin{tabular}{|l|c|c|c|c|c|}
\hline \multicolumn{1}{|c|}{ Amount in $€$ millions } & North-West & North-East & Center & South & Italy \\
\hline $\begin{array}{l}\text { No. of Confidi enrolled in the register } \\
\text { of whom: under supervision of the Bank of Italy }\end{array}$ & 98 & 80 & 133 & 306 & 617 \\
\hline $\begin{array}{l}\text { Data from Central Credit Register } \\
\text { No. of Confidi present in CCR }\end{array}$ & 88 & 80 & 113 & 223 & 504 \\
total value of issued guarantees & 8.549 & 5.245 & 4.463 & 3.943 & 22.200 \\
$\quad$ of whom: issued by Confidi 107 & 7.064 & 3.819 & 3.483 & 1.727 & 16.093 \\
\hline Guarantees offered by each Confidi & 97.1 & 61.7 & 39.5 & 17.7 & 43.6 \\
Value of guarantees (average) & 415.5 & 212.1 & 290.3 & 132.9 & 268.2 \\
$\quad$ of whom: of Confidi 107 & 21.1 & 25.7 & 3.5 & 4.3 & 6.1 \\
\hline $\begin{array}{l}\text { Guarantees offered by each Confidi } \\
\text { Value of guarantees (median) } \\
\text { of whom: of Confidi 107 }\end{array}$ & 176.8 & 129.8 & 119.1 & 119.5 & 134.3 \\
\hline Extension of penetration of Confidi & 18.7 & 16.0 & 11.3 & 6.4 & 11.3 \\
$\quad$ No. of provinces (average) & 12.5 & 12.0 & 6.0 & 4.0 & 6.0 \\
$\quad$ No. of provinces (median) & 6.8 & 6.9 & 5.1 & 3.1 & 4.8 \\
$\quad$ No. of regions (average) & 5.0 & 6.0 & 3.0 & 2.0 & 3.0 \\
$\quad$ No. of regions (median) & & & & \\
\hline
\end{tabular}

(*) Geographical allocation is based on the registered seat of Confidi.

Source: Central Credit Register (CCR), Bank of Italy

The national data confirms the local-level findings, although there persist significant differences in absolute values of non-performing credits: in Southern Italy the non-performing credits guaranteed by Confidi are $21.2 \%$ and $37.8 \%$ in case of non-performing credits not guaranteed by Confidi, in Central Italy respectively $19.9 \%$ and $22.3 \%$, in North-East $11.7 \%$ and $12.2 \%$ and in North-West $15.8 \%$ and $18.2 \%$.

\section{Law 1259 \\ a) The reasons of the reform}

4. 2015: The actual draft of reform - Draft of

At the end of 2012, there were 637 Confidi in Italy, 57 of them directly supervised by the Bank of Italy. Their number continues to decrease in accordance with the process of aggregation, mainly implemented through consecutive mergers, in order to achieve the required dimension to be enrolled in the Register of Regulated Intermediaries and essentially pass from Confidi 106 to Confidi 107. In dimensional terms, the distribution of Confidi is fragmented, as a small number of
Confidi hold half of the market and the smallest Confidi generally are located in Southern Italy.

On the front of risk management, there is a noticeable decrease of guarantees in terms of risk of credit: the trend is a more restrictive policy of issue of guarantees, in particular for Confidi supervised by the Bank of Italy, connected to the more generic policy of general deleveraging by credit intermediaries as a consequence of the increasing burden of non-performing credits.

Because of the policy of rates that is not yet fully risk-based and of the high incidence of operative costs on their profitability margins, Confidi don't generate satisfactory economical outcomes. Furthermore, the quantitative progressive reduction of State aid allocated to Confidi in recent years reduces the possibility to stock capital for future risks management.

Still the coefficient of solvency for Confidi supervised by Bank of Italy respects law requirements but a new reform is considered necessary. 
Table 2

Incidence percentage of non-performing loans over loans guaranteed by Confidi to enterprises of minor dimension organized by economic sector, regions and Macro-areas $\left(\mathrm{a}^{14}\right)$

\begin{tabular}{|c|c|c|c|c|c|c|c|c|c|c|}
\hline \multirow{2}{*}{ Regions and Macro areas } & \multicolumn{2}{|c|}{ Total loans (b) } & \multicolumn{2}{|c|}{ Agriculture } & \multicolumn{2}{|c|}{ Services } & \multicolumn{2}{|c|}{ Construction } & \multicolumn{2}{|c|}{ Manufacturing } \\
\hline & B & A & B & A & B & A & B & A & B & A \\
\hline Piemonte & 15.2 & 27.6 & 5.8 & 8.1 & 15.8 & 29.5 & 19.2 & 34.4 & 20.4 & 27.4 \\
\hline Valle d'Aosta & 23.7 & 4.2 & 4.8 & 0.5 & 27.8 & 3.6 & 177 & 6.6 & 23.8 & 5.7 \\
\hline Lombardia & 15.2 & 16.2 & 10.0 & 5.0 & 13.8 & 16.6 & 22.9 & 25.9 & 18.7 & 15.2 \\
\hline Liguria & 18.5 & 15.3 & 18.4 & 13.8 & 17.2 & 16.1 & 24.4 & 19.9 & 19.9 & 10.8 \\
\hline Trentino Alto Adige & 5.2 & 10.4 & 1.8 & 1.8 & 4.7 & 9.7 & 11.8 & 18.9 & 6.0 & 10.8 \\
\hline Veneto & 15.0 & 13.6 & 7.4 & 4.3 & 13.6 & 11.6 & 22.9 & 24.8 & 22.0 & 14.2 \\
\hline Friuli Venezia Giulia & 13.4 & 13.7 & 5.6 & 9.3 & 13.0 & 13.8 & 23.5 & 25.2 & 19.6 & 11.0 \\
\hline Emilia Romagna & 15.3 & 8.9 & 8.9 & 2.9 & 13.7 & 9.3 & 26.7 & 18.0 & 18.1 & 10.5 \\
\hline Toscana & 18.1 & 18.2 & 15.3 & 12.4 & 15.2 & 16.2 & 26.0 & 25.5 & 24.8 & 18.5 \\
\hline Umbria & 22.7 & 26.2 & 18.4 & 22.8 & 19.2 & 26.7 & 32.0 & 27.1 & 29.8 & 25.8 \\
\hline Marche & 20.4 & 14.8 & 11.7 & 8.8 & 18.4 & 14.1 & 28.2 & 19.0 & 27.5 & 15.4 \\
\hline Lazio & 28.1 & 20.5 & 23.3 & 1.8 & 25.3 & 18.9 & 41.0 & 23.3 & 37.3 & 29.3 \\
\hline Abruzzo & 24.8 & 15.8 & 21.8 & 13.7 & 23.1 & 14.1 & 26.0 & 21.0 & 33.4 & 17.2 \\
\hline Molise & 38.2 & 25.3 & 26.8 & 13.2 & 31.4 & 22.7 & 63.0 & 34.4 & 39.1 & 27.1 \\
\hline Campania & 35.0 & 30.4 & 29.6 & 15.1 & 30.2 & 29.4 & 53.9 & 35.4 & 42.8 & 34.2 \\
\hline Puglia & 33.1 & 12.4 & 32.6 & 6.6 & 28.5 & 12.0 & 48.1 & 16.2 & 36.2 & 13.5 \\
\hline Basilicata & 46.6 & 15.4 & 41.4 & 18.9 & 40.1 & 14.2 & 63.0 & 19.4 & 49.3 & 13.0 \\
\hline Calabria & 47.1 & 31.1 & 44.4 & 20.9 & 42.0 & 28.8 & 60.5 & 38.1 & 54.3 & 36.8 \\
\hline Sicilia & 41.4 & 19.2 & 40.5 & 19.1 & 36.0 & 17.9 & 58.5 & 21.6 & 45.2 & 21.8 \\
\hline Sardegna & 36.0 & 20.1 & 38.7 & 8.4 & 28.8 & 19.1 & 50.5 & 27.4 & 46.4 & 23.5 \\
\hline North-West & 18.2 & 15.8 & 9.8 & 6.9 & 18.7 & 16.5 & 60.9 & 21.7 & 20.7 & 14.8 \\
\hline North-East & 12.2 & 11.7 & 5.9 & 4.6 & 11.3 & 11.1 & 21.2 & 21.7 & 16.4 & 11.6 \\
\hline \begin{tabular}{|l|} 
Centre \\
\end{tabular} & 22.3 & 19.9 & 17.2 & 11.5 & 19.5 & 19.0 & 31.8 & 23.7 & 29.9 & 22.3 \\
\hline South & 37.8 & 21.2 & 34.5 & 14.5 & 32.5 & 19.8 & 52.9 & 26.7 & 43.3 & 23.4 \\
\hline Italy & 20.9 & 16.2 & 14.6 & 6.6 & 18.9 & 16.1 & 31.6 & 23.9 & 25.5 & 17.0 \\
\hline
\end{tabular}

14 (a) Geographical allocation is based on the registered seat of guaranteed enterprises; data referred to those Confidi indicated as issuers of guarantees of a higher volume if compared to the threshold of individual survey, 31.12.2013

Enterprises of minor dimensions are to be considered not financial enterprises with less than 20 workers. The value of each macro-area is obtained as the mathematical mean of the values of regions included into the macro area.

(b)The total of the guarantees issued includes also guarantees issued not included in the indicated sectors of activity.

A. Enterprises guaranteed by Confidi; B. Enterprises not guaranteed by Confidi

Source: Central Credit Register, Bank of Italy. 


\section{b) Draft of Law 1259}

\section{The Draft of Law}

On July, 2015 the Senate of Italy approved Draft of Law No. 1259 containing a mandate to the Government to organically reform the system of the Confidi.

The ultimate goal of the reform is to promote development of the Confidi and therefore facilitate access to credit by SMEs. By means of the approval, the Chamber of Senate authorizes the Government to introduce effective measures to promote and encourage the capitalization of Confidi, to improve conditions and processes of resources accumulation and to enhance the effect of the intervention of each single actor in the chain of supply of guarantees and counterguarantees issue. An introduction of measures aimed at reducing the compliance of bureaucratic oppressive provisions for the Confidi is also expected, charging most of the provisions on banks and therefore avoiding overlapping of interventions and bureaucratic slowness of procedures, reducing the resulting managerial and procedural inefficiencies as well as structural operative costs. The leitmotif is simplification.

Essentially, the main actions proposed are the following ${ }^{15}$ :

1. Promote the recapitalization of the Confidi and facilitate the accumulation of resources, deriving from public, private or from third sector actors, of current assets and of stock, identifying instruments and Basel-compliant modalities to use them in order to facilitate the access to credit for SMEs;

2. Regulate and readdress the modalities of allocation of public financial support aimed at the capitalization of Confidi in compliance with EU regulations

3. about State aid;

4. Rationalize and accelerate the chain of guarantees and counter-guarantees by optimizing the relationships between banks, Confidis and companies, thus fostering the restructuring of organizational models and of the chain of creditguarantee-banks, Confidi, local authorities, Chambers of Commerce;

${ }^{15}$ See papers on the argument on the web page of the Italian Senate http.//www.senato.it.
5. Develop forms of guarantees and instrumental collateral services, financial and non-financial, satisfying the new requirements of SMEs

6. Reinforce the proportionality and specificity criteria $^{16}$, extending their implementation to all the legislations about the Confidi,

\section{Some proposals}

The principles of the reform have been widely endorsed by actors of the field, institutions and experts invited during the related cycles of parliamentary debates.

All of them agree about the importance of the recapitalization of the Confidi and of the implementation of collateral instruments and services offered to SME associates.

In the phase of economic cycle in which we are experiencing widespread crises, the Confidi should have enough capital to absorb the risks associated with their business, even in stressful situations, ensuring continuity and efficiency of services to their customers and ability to act as intermediaries of adequate operating efficiency. In order to realize effectively the recapitalization of Confidi, it is first of all necessary to remove some obstacles which restrain its actualization.

First, the fragmentation and dispersion of public aid, often characterized by one-spot intervention, difficult to evaluate in terms of results and effectiveness of intervention. It is necessary to implement a model of systematic long time structured planning of public aid, enabling a clear time sheet of planned volumes and measures of disbursement. It would imply on one hand the possibility for each single Confidi to fulfil long-term strategic planning, (and therefore the connected internal scheduling of timing and volumes of issuable guarantees), and on the other hand, the policy maker could evaluate the effectiveness of the measures adopted adjusting in case of their selection. The activation of a national database collecting all existing measures of public aid (state, regional, of Chambers of Commerce, FEI, of other public institutions) and reporting their factual impact on their theoretical final beneficiaries could be useful.

${ }^{16}$ Sanctioned by the Itallian Consolidated Law on banking in its most recent formulation. 
Simultaneously, it would be advantageous to create a mechanism of reward for the most effective Confidi, directing facilitations or public reliefs for instance to those Confidi which offer greater operative volumes of guarantees issued. To implement it, the Confidi should accomplish the requirement of the fulfilment of an accountability about the modalities of employment of the public resources and should be implemented an evaluation system about these Confidi. To reinforce also the mutualistic nature of the Confidi, it would be advantageous to correlate, through appropriate parameters, the amount of guarantee issued in favour of each enterprise to the amount of capital that each enterprise allocated to a Confidi to capitalize it.

In the actual situation of high general incidence of non-performing credits, it is furthermore advisable to distinguish between an ordinary public aid (aimed at supporting in an ordinary situation the enhancement of guarantees issued by 'healthy' Confidi) and an extraordinary public aid (aimed at insuring evident situations of crisis or weakness). In this latter case (extraordinary public aid), it would be possible to include the extraordinary public aid in a wider framework that considers the management of the non performing credits of the banking system towards SMEs as a whole and the creation of a bad-bank for the banking system managing nonperforming credits. Just for the Confidi registered in the Register of Regulated Intermediaries identifying the technical forms of Basel-compliant public aid should be opportune, so volumes of new guarantees issuable by Confidi should be expanded. The capitalization of the Confidi could be implemented extending the range of their shareholders. The Confidi could consider as possible ordinary shareholders not only large financial enterprises/public and private entities/ banks and other financial institutions (with limited shares); a juridical figure of the 'socio sovventore ${ }^{17}$, literally 'promoter shareholder' should be introudced (just for the Confidi organized in the juridical form of cooperatives).

17 'Socio sovventore' is a specific type of shareholder recently juridically introduced in some types of Italian cooperatives and with the main function of capitalization on the side of cooperatives and of perceiving of a profit on the side of 'socio sovventore'.
Besides the capitalization of the Confidi, of relevance is also the development of the collateral services that Confidi can promote in order to support the development of SMEs in the actual scenario. They could offer continuous support to the financial management of associated SMEs, implementing SMEs system of financial planning and scheduling. Therefore, they could become a reliable intermediary of banks about the solvency of the SMEs associated and the reliable interlocutor of associated SMEs to prevent or restore financial problems.

Considering the possibility to offer further services to support access to credit for SMEs, Confidi could also grant mutual guarantees in order to cover partially mini-bonds issued by Italian SMEs not listed on the Stock Exchange ${ }^{18}$, as well as grant guarantees to subjects recently authorized to grant credits $^{19}$. The Confidi could also take part in more sophisticated interventions, such as tranched covers.

These are just some proposals of the activities that the Confidi could actuate, but still sufficient to reveal the enormous potential of the Confidi.

5. Conclusions. Confidi are recognized as a pillar of the Italian guarantee sector. Their historical origins and their ability to accompany the Italian enterprises efficiently through all the different phases of their progressive evolution reveal the indissoluble connection that ties them tightly with the economic development of Italy.

Therefore, the challenge to develop factual legislative instruments appropriate to support their development and to fulfil the required reforms of the Confidi system is actually be considered as an essential part of the global challenge of Italy to enhance national competitiveness in the next decades.

${ }^{18}$ Legislative Decree No 83/2012 and Legislative Decree No. 145/2013 have introduced the possibility for SMEs not listed on the Stock Exchange to capitalize themselves issuing mini- bonds exclusively addressed to or assured by qualified investors

${ }^{19}$ Legislative Decree No. 91/2014 has authorized to grant credit some additional institutions respecting established parameters, such as insurance agencies and the national insurance agency SACE (www.sace.it). Such institutions therefore are to become potential interlocutors of Confidi. 


\section{REFERENCES}

1. Kozlov A.V., Sanneris D. Podderzhka vneshneekonomicheskoi deiatel'nosti malykh i srednikh predpriiatii: ital'ianskii opyt. Rossiia $v$ global'nom mire. 2013. № 3(26). S. 46-54. (rus)

2. AECM - Leaflet of AECM Members: figures 2013, June 2013.

3. AECM - AECM Scoreboard : Figures of the European Guarante Sector providing a half 2015ly trend indication of the evolution of the Guarantee activity in Europe H1 2013 - H2 2014, 2013.

4. Alleanza delle Cooperative italiane, Appunto dell'Alleanza delle Cooperative italiane per l'audizione in tema di disegno di legge delega al governo per la riforma del sistema dei confidi (n. 1259), 17 luglio Register of Bank of Italy, 2014.

5. AA.VV., I confidi e il credito alle piccole imprese durante la crisi, a cura di Mistrulli P.E. e Vacca V. Questioni di Economia e Finanza, 2011, no. 105.

6. Amaturo F., Giordano L., Petraglia C. L'equilibrio gestionale dei Confidi in Italia prima della crisi, un'analisi territoriale, in Rapporto SVIMEZ su relazioni banca-impresa e ruolo dei Confidi nel Mezzogiorno. Mercato, regole e prospettive di sviluppo. Quaderni SVIMEZ, 2013, no. 36, pp. 69-86.

7. Amaturo F., Giordano L., Petraglia C. I Confidi nella crisi: riforme, nuovi assetti e vecchie sfide. Rivista Economica del Mezzogiorno, 2014, no. 4, pp. $857-880$.

8. Arping S., Loranth G., Morrison A. Public Initiative to Support Entrepreneurs: Credit Guarantee vs. CoJournal of Financial Stability, 2009, no. 6, pp. 23-35.

9. Bank of Italy, L'economia delle regioni italiane nel 2013. Economie regionali, 2014, no. 21, luglio, Roma.

10. Busetta G., Presbitero A. Confidi, piccole imprese e banche: un'analisi empirica, in A. Zazzaro (ed.). I vincoli finanziari alla crescita delle imprese, 2008.

11. Carpinella A. (ed. by) Credit guarantee: a public good between State and Market, Bancaria Editrice, 2012.

12. Columba F., Gambacorta L., Mistrulli P.E. Mutual Guarantee Institutions and Small Business Financial. Bank of Italy working papers, 2009 b, no. 735.

13. Dell'Atti S. Miani, Economia e gestione dei confidi, 2014, FrancoAngeli.

14. Erzegovesi L. Disegno di legge n. 1259 Delega al Governo per la riforma del sistema dei confidi, Audizione presso la Commissione VI del Senato della Repubblica, 2014.

15. Leone P., Vento G. Credit Guarantee Institution and SME Finance, Palgrave Macmillan, 2012.

\section{СПИСОК ЛИТЕРАТУРЫ}

1. Козлов А.В., Саннерис Д. Поддержка внешнеэкономической деятельности малых и средних предприятий: итальянский опыт // Россия в глобальном мире. 2013. № 3(26). С. 46-54.

2. AECM - Leaflet of AECM Members: figures 2013, June 2013.

3. AECM - AECM Scoreboard : Figures of the European Guarante Sector providing a half 2015ly trend indication of the evolution of the Guarantee activity in Europe H1 2013 - H2 2014, 2013.

4. Alleanza delle Cooperative italiane, Appunto dell'Alleanza delle Cooperative italiane per l'audizione in tema di disegno di legge delega al governo per la riforma del sistema dei confidi (n. 1259), 17 luglio Register of Bank of Italy, 2014.

5. AA.VV., I confidi e il credito alle piccole imprese durante la crisi, a cura di Mistrulli P.E. e Vacca V. // Questioni di Economia e Finanza, 2011, no. 105.

6. Amaturo F., Giordano L., Petraglia C. L'equilibrio gestionale dei Confidi in Italia prima della crisi, un'analisi territoriale, in Rapporto SVIMEZ su relazioni banca-impresa e ruolo dei Confidi nel Mezzogiorno. Mercato, regole e prospettive di sviluppo // Quaderni SVIMEZ, 2013, no. 36, pp. 69-86.

7. Amaturo F., Giordano L., Petraglia C. I Confidi nella crisi: riforme, nuovi assetti e vecchie sfide // Rivista Economica del Mezzogiorno, 2014, no. 4, pp. 857-880.

8. Arping S., Loranth G., Morrison A. Public Initiative to Support Entrepreneurs: Credit Guarantee vs. Co- // Journal of Financial Stability, 2009, no. 6, pp. 23-35.

9. Bank of Italy, L'economia delle regioni italiane nel 2013 // Economie regionali, 2014, no. 21, luglio, Roma.

10. Busetta G., Presbitero A. Confidi, piccole imprese e banche: un'analisi empirica, in A. Zazzaro (ed.) // I vincoli finanziari alla crescita delle imprese, 2008.

11. Carpinella A. (ed. by) Credit guarantee: a public good between State and Market, Bancaria Editrice, 2012.

12. Columba F., Gambacorta L., Mistrulli P.E. Mutual Guarantee Institutions and Small Business Financial // Bank of Italy working papers, 2009 b, no. 735.

13. Dell'Atti S. Miani, Economia e gestione dei confidi, 2014, FrancoAngeli.

14. Erzegovesi L. Disegno di legge n. 1259 , Delega al Governo per la riforma del sistema dei confidi, Audizione presso la Commissione VI del Senato della Repubblica, 2014.

15. Leone P., Vento G. Credit Guarantee Institution and SME Finance, Palgrave Macmillan, 2012.

SANNERIS G. - University of Modena and Reggio Emilia

Strada Vignolese. 905-41125. Italy. E-mail: giada.sanneris@gmail.com

САННЕРИС Джада - профессор Университета Модена и Реджио Эмилья, M.Sc.

ул. Вигнолезе, 905-41125б, Италия. E-mail: giada.sanneris@gmail.com

(C) St. Petersburg State Polytechnical University, 2015 